\title{
KULEUVEN
}

\section{Key issues in educational policy for secondary schools in federated Belgium}

The final publication is available at http://www.tandfonline.com/doi/abs/10.1080/0268093920070108\#.VC5uVU0cRMw

VERHOEVEN, J. C. (1992) "Key issues in educational policy for secondary schools in federated Belgium." Journal of Education Policy. 7 (1) pp. 99-107 



\title{
Key issues in educational policy for secondary schools in federated Belgium I' I
}

\author{
Jef C. Verhoeven
}

To understand Belgian educational policy, it is necessary to keep in mind two important characteristics: (1) Belgium has changed recently from a centralized state to a federal state, a process which is not yet completed, and (2) Belgium is a polarized society.

Belgium has a national parliament and a national government, which have responsibilities that largely differ from those of the Communities and the Regions. There are three Communities: the Dutch-speaking (Flemish), the French-speaking and the Germanspeaking. There are also three Regions: the Brussels Region (bilingual Dutch and French), the Flemish Region, and the Walloon Region (bilingual French and German). The Communities and Regions have parliaments and executive bodies and are funded by the national government. The major part of the educational policy is the responsibility of the Communities, although some matters are under the authority of the national government. The Flemish Region and Community have one parliament, one executive body and one budget. This is not the same for the French-speaking part of the country: the Walloon Region and the French Community have separate parliaments, executive bodies and budgets. As will be shown later, the split budgets in the French-speaking area have created serious problems for educational policy in that part of the country.

Another important factor in educational policy is the polarization of Belgian society. Traditionally, Belgium was Catholic and could rely on an extensive network of organizations for social welfare and schools sponsored by the Catholic church. In the 19th century, Socialist and Liberal groups were also formed and became the defenders of a neutral education, organized by the state, provincial and local authorities. This opposition was often the cause of fierce controversies between Catholic organizations defending free or religious schools and Socialist and Liberal organizations promoting neutral state schools. Private schools, the majority being Catholic, traditionally were defended by the Christian-democratic parties (the CVP and the PSC), while state education was supported by the Socialist (the SP and the PS) and Liberal (the PVV and the $\mathrm{PRL}$ ) parties. Although the majority of the Belgian population certainly no longer practises the Catholic religion (Dobbelaere 1988: 47), Catholic schools still attract the majority of the pupils, as shown in table 1 , and the proportion has been increasing in recent years.

(here Table 1)

Flanders not only sends a larger proportion of its youngsters to Catholic schools than Wallonia but also votes more for the Christian-democratic party and has a larger membership in the Christian trade unions than does Wallonia. This different political reality understandably affects the educational policy in the three Communities, which have been determining their own educational policy since 1989.

The educational system in the three Communities is developing in different directions, and the issues are no longer the same in the three Communities. For example, while most of the secondary schools in the French-speaking Community are organized in a 
comprehensive system, there was strong resistance to comprehensive schools in Flanders, where a unitary system was instituted in 1989 in which the traditional multilateral and comprehensive systems were reconciled. However, equality of financial support of community and private schools is still an important issue in the three Communities, which have also to cope with the austerity policy of the national government.

In this paper, four key issues concerning secondary education will be discussed: (1) the position of the teachers; (2) quality of education; (3) local school administration, and (4) the education of the children of immigrants. The analysis will mainly be focused on the Dutch- and French-speaking Communities.

\section{The position of the teachers}

Teachers are considered to be peaceful people. Their rights were usually defended by the trade unions and, if the government was reluctant to meet their demands, rallies would be organized. Sometimes there were very short strikes, no longer than a day. This behaviour changed in 1990 when teachers in Wallonia went on strike for more than eight weeks. Why? This strike reflected a malaise in schools, which occurred not only in Wallonia but in Flanders as well. Nevertheless, the Flemish teachers did not strike, for reasons I will discuss later.

Trade unions, organizations of directors and researchera recognize similar reasons for malaise in Belgium as in other countries (Ravez and Tistaert, 1991:330, FEADI 1991). Teachers have the feeling that they have lost the prestige that was traditionally attached to their profession. Too many parents and children fail to appreciate the work of the teachers. In comparison with other occupations, they have the impression that their salary is very low and has not risen sufficiently. It took 18 years before the Flemish Executive granted teachers in private schools a new legal status comparable to that of their colleagues in state schools. This is not the case in Wallonia: teachers in private schools are still waiting for appropriate legal status. Since most of the teachers spend their entire career teaching, there is no real challenge. Young but also older teachers have less employment security because of the drop in the birth rate. If they lose their job they are placed in redeployment programmes which are not approved of by either teachers or headteachers.

Research has shown that the critical element in job satisfaction of teachers is the quality of their relations with the pupils and the head. This might explain why teachers in some comprehensive schools, confronted with a wide variety of pupils as far as school aptitude is concerned, are dissatisfied. It could also explain the unhappy feelings of teachers about the management style of their headteacher.

Other factors explaining job dissatisfaction of teachers are, for example, the reduction of paid hours for counselling and class councils, sometimes the lack of educational materials and the lack of a clear educational concept.

All these factors together stimulated a general feeling of dissatisfaction by teachers towards their job. In the last two years, this feeling was present in Flanders as well as in Wallonia, but certainly stronger in the latter. The French-speaking part of the country was the scene of several days of strikes by teachers in June 1990, and several weeks in September, October and November 1990. In many French-speaking schools, teachers 
took such a strong position that no examinations were organized at the end of the school year 1989-1990 or before the Christmas holidays in 1990. This action did not receive the complete support of the parents, who feit their children had the right to education, although many among them could understand why the teachers went on strike.

Although the same malaise was found among the Flemish teachers, they did not strike. The Minister of Education started negotiations ('Herfstoverleg') with the organizing authorities, the trade unions, parents' groups and educationalists about the revaluation of the teachers' position and participation structures in schools. Teachers had the feeling that the government was listening to their problems. The trade unions were able to come to an agreement with the government: teachers obtained an increase (6\% spread over three years) in pay; teachers in private schools obtained legal status, and the status of the teachers in state schools was adapted to their changed expectations (Decree of 21 March 1991).

At the end of their protests, the French-speaking teachers received the same increase as the Flemish, but why did they have to go on strike to achieve this? From the outset it was clear that the French-speaking Community could not pay the increase in the salaries demanded. The Dutch-speaking community could afford this increase because it has one single budget together with the Flemish Region. But what is possible now, might be impossible in the future. W. Nonneman (1991) has calculated that, if the law regulating the financing of education in the Communities is not changed before 1998 as is required by law, the Dutch-speaking Community will receive 19\% less than necessary to pay for its schools and the French-speaking Community 26\% less. Because the French-speaking Executive gave the impression that no increase of salaries was possible, Frenchspeaking teachers chose to go on strike. On Thursday, 1 August 1991, the national government announced the expansion of the financing of the Communities and the right of the Communities to collect taxes to allow them to have the necessary money for education for the time being.

Guaranteeing the financial and social recognition of teachers will remain one of the main issues in educational policy. Even though a survey in Flanders has shown that nine out of the ten teachers want to remain in education (Van Hooreweghe 1991), this does not mean that they are satisfied with their position. Indeed, $20 \%$ of the male and $8 \%$ of the female teachers were actively seeking other work.

\section{The quality of education}

Quality of education is, of course, a key issue of all educational systems. That educationalists and educational policy makers in Belgium worry a lot about the quality of education is partly because of the large proportion of pupils (in 1987-88 in Flanders $12.6 \%$; in 1985-86 in Wallonia $29.5 \%$ ) who complete primary school with a delay of at least one year and an even larger proportion of pupils who complete secondary school with the same delay (in 1987-88 in Flanders 40.1\%; in 1985-86 in Wallonia 58.8\%). The proportion of pupils who graduate from secondary school with a delay of at least one year is larger for foreign pupils than for Belgians, larger in technical and vocational schools than in grammar schools, and is larger in state and local authority schools than in private schools. One reason for this delay is the small amount of the appropriate cultural capital available for pupils whose parents are foreigners or belong to the lower class. Grisay and Van Damme (1991) allo cite the following reasons: staying in the same grade is the only way pupils have to control the pace of schooling; the differences between schools in 
educational quality; the competition between public and private education and between schools; an educational policy that is more interested in curing than preventing; and an assessment of children based on excessively high standards.

The Minister of Education, D. Coens, made many structural changes to improve the situation. The start of comprehensive education in 1969 was intended to contribute to the solution of the problem of the many failures in secondary schools. This structure still exists in Wallonia, but it has been reorganized in Flanders. The unified studies curriculum school structure in Flanders still has a curriculum with many common subjects at the beginning of the secondary school and specializing in the later years. For pupils with transition problems from primary to secondary school, special classes are organized. Teachers are supposed to assess pupils continuously and not just at the end of a term. And, in order to detect pupils' learning problems early, psychological counselling offices can advise parents, pupils, headteachers and teachers.

Apart from these structural measures, some experiments have been launched recently. In the French Community the Executive has set up 'ZEP' projects (Zones d'éducation prioritaire). These are zones with more pupils than average in the category of disadvantaged children. Schools in these zones are receiving special support for four years. The programme covers pupils in primary school and the first three years of secondary school. Moreover, in all three Communities, special programmes have been organized in vocational and technical schools in order to help motivate pupils.

Special attention will have to be paid to the organization of school inspection, educational guidance, and extra training, three instruments for protecting and improving the quality of education. The Decree of 10 July 1991 gave Flanders a new inspection and guidance structure, different from that in Wallonia.

First, let us examine inspection in the French- and German-speaking Communities because this was, until September 1991, the general Belgian pattern. Here there are two kinds of inspectors, the Community inspectors and the inspectors employed by the governing authorities of the schools. The Community inspectors determine whether schools meet the minimal standards of the curriculum, and see to the application of the language laws, the protection of the health of pupils and teachers, and the material equipment of the schools as prescribed by the Minister of Education. In non-Community schools these inspectors have no right to supervise the didactics of the teachers. Noncommunity schools have their own inspection system, which is not paid for by the Community (Counet and Vandenberghe 1991). Educational guidance in Community schools is part of the job of the inspection service, while there are special officers for guidance connected with the governing authorities of the non-Community schools. Extra training is organized by the inspection service and the governing authorities, mainly in relation to school innovation programmes (such as conversion to comprehensive schools).

Many educationalists and policy makers in Flanders were not satisfied with this system because inspection very often got most of the attention at the expense of guidance. In Flanders, the Decree of 10 July 1991 provides a special inspection service which was due to start in September 1991. This inspection service will have the same tasks as its predecessor but will be structured and will function differently. Half of the inspectors will be recruited from the public schools and the other half from the private schools but all will be paid by the Community. Another innovation will be that the inspectors will no longer 
function as individuals but as teams and will check the school, not the individual teacher. Title III of this decree entitles all governing authorities to create offices for educational guidance to improve the quality of education. The objective is to adapt these offices to provide help for local problems. Title IV of the decree creates a legal structure and financing for a better organized system of extra training for teachers. The Flemish Minister of Education, D. Coens, hopes that this new structure will be able to respond better to problems of quality of education. To what extent this will be true promises to be one of the most important issues in Belgian educational policy.

\section{Local school administration}

In spite of territorial and functional educational decentralization since the beginning of the Belgian state, Belgium has had a rather centralized educational system: the control of the tentral state has always been very important, even for education organized by local authorities and private bodies. On 1 January 1989, educational policy was transferred completely from the federal state to the three Communities, but indications of decentralization were already previously apparent. Since 1984/85, the ministers of education have allowed more freedom to the school heads to adjust the available period/teacher ratio in relation to the local educational policy. Moreover, the law of 31 July 1984 granted more financial autonomy to school heads of state schools (Verhoeven et al. 1991). In the German-speaking and the French-speaking Communities local school administration is still confined to these areas. This was not the case in the Dutchspeaking Community where decentralization went much further.

What are the key issues in relation to local school administration in Flanders? A distinction must be made between the community schools and the subsidized schools.

Traditionally, the Minister of Education was the organizing authority of the state schools. When the Flemish Community obtained the authority to organize education, the political parties wanted to dissociate the Community schools from the hazards of polities. If the Minister of Education were the organizing authority of Community schools, educational policy in Community schools might be too dependent on a volatile political climate. For this reason the Autonome Raad voor het Gemeenschapsonderwijs (Autonomous Council of Community Education) was established in 1989 as an independent body for Community schools. These schools do not receive a subsidy as do private and local authority schools, but receive enough money to provide free education. Until 1 April 1991, all decisions for local schools were made by this central body or by the local councils inherited from the central state. From then on, many rights of the central council were delegated to the 374 local school councils. One-third of the members of these local school councils are elected locally by the parents, and these elected members choose the rest of the members from the school staff and from local social, economic and cultural associations. Since these local school councils are intended to organize ideologically neutral education, it was expected that members from the entire political spectrum would be elected. This did not happen. According to the newspaper De Standaard (15 January 1991) and Het Volk (11 January 1991), citing a report from the Christian-democrats, $50 \%$ of the elected members were Socialists, $15 \%$ Liberals and $7 \%$ Christian-democrats. The political background of the remaining members was not clear. Like many other organizations, the local school councils came under increasing pressure from different parties in this polarized society. Many are afraid that, as in many other sectors of Belgian public administration, teachers will be selected not for their professional qualifications but for their membership of political parties or trade unions. Others fear that the Community 
schools, although they should be ideologically neutral, might turn out to be mainly for children of Socialist or Liberal families.

When the Flemish Executive stipulated clearly in Title VIII of the Decree of 31 July 1990 that school heads should be advised by representatives of parents and teachers on some decisions, it was not the first time that participation in school administration had been granted to teachers and parents. Until then, however, the degree of participation of teachers and parents varied considerably from school to school. And, while teachers had a certain voice in the administration, parents were not really partners (Devos et al. 1989). Not all schools have parents' organizations and, if they do, most of their time is spent discussing fund raising and non-curriculum problems. The new regulations of this decree clearly demand the representation of parents in school operations, which was already regulated for Community schools by decree (local school councils) but not for the nonCommunity schools. How this participation of parents should be organized became an important issue in private schools. Within the NSKO (National Secretariat of Catholic Education) an agreement was made between the organizing authorities of the Catholic schools and the Catholic Parents Association. This agreement will be part of a new decree on participation in schools, scheduled for debate in the Flemish parliament at the end of 1991. In the meantime, national parent associations are publishing information and organizing special training for parents who want to participate in the local school councils (Veny 1991). In spite of this, it is not certain that the participation of parents will have an appreciable influence on school administration. If the past is an indicator of the future, the influence of parents will be insignificant, because they lack skili or even interest in school administration.

\section{Education for children of immigrants}

Belgium is a multicultural society that has to take into account the cultural differences of the autochthons and also chose of the many resident foreigners. In $1989,8.8 \%$ of the population in Belgium were foreigners: $4.2 \%$ of the population in the Flemish Region, $11.3 \%$ in the Walloon Region and $27.2 \%$ in the Brussels Region (KCMB 1990a). Although policy makers were not unaware of the integration problems created by high concentrations of foreigners in some neighbourhoods, it was not until the 1980s that a policy began to be formulated. A very significant step was the appointment of a royal commissioner for policy in relation to immigrants in March 1989. The reports produced by this commissioner (KCMB 1989a,b, 1990a,b) together with the experience, violent and non-violent, in some schools and neighbourhoods, gave rise to a better educational policy for immigrant children. Since foreign west European and American children generally attend private English schools, they do not have the problems which the majority of children of immigrant workers have. Here the discussion is confined to the educational problems of immigrant children coming mainly from southern Europe, the Maghreb countries and Turkey.

As the figures cited above imply, the problem of the organization of education for the children of immigrants is not the same for each Community (Table 2).

(here Table 2)

One problem in the integration of immigrant children is that they are not equally distributed amongst the schools. Some cities, and Brussels in particular, attract most of the migrant workers. Some neighbourhoods in Brussels and in other cities are populated 
mostly by Turkish or Maghreb migrant families. The consequence is that $39.15 \%$ of the primary schools in Brussels have more than $50 \%$ of their pupils coming from immigrant families. Indeed, three schools have no Belgian pupils at all. Many of these schools are located in neighbourhoods with a strong concentration of Muslim migrant families, which does not facilitate integration into a mainly Christian culture (Leirman et al. 1991; KCMB 1990a).

Belgian society has become aware not only of the problem of integration of immigrant families but also of the necessity to make the autochthons aware that they live in a multicultural society. In terms of educational policy, this means that education should prepare the immigrant children for integration into Belgian society and also should enable Belgian pupils to understand other cultures.

Belgian educational policy intends to integrate immigrant children and adults but at the same time to give them the opportunity to develop their ethnic identity. It also intends to accelerate the educational progress of immigrant children and to reduce the number who require special education.

To attain these goals the Flemish Minister of Education (Coens 1991) launched a project to give special support to schools and neighbourhoods with many immigrant children. This policy is meant for nursery and primary schools and the two first years of secondary school. While recognizing the freedom of the parents to choose the school they should be avoided in order to make contact with the other culture easier. Schools in problem areas receive support from the government for hiring more teachers and for community programmes to improve relations between the school and the immigrant families. In the schools, teachers are encouraged to develop 'intercultural education', i.e. they should help the pupils to acquire the knowledge, skins and attitudes needed to function adequately in a multicultural society. Schools should devote special attention to recently arrived children (special temporary classes and lessons). If two-thirds of the parents of a foreign ethnic group in a primary school representing at least 20 children request 'Onderwijs in eigen taal en cultuur' (education in their own language and culture) schools may organize such classes. Native teachers may be hired to teach these pupils. Two models are possible: the bicultural model in which $50 \%$ of the classes are taught in the ethnic language, and the supporting model in which $20 \%$ of the classes are taught in the ethnic language of the pupils. A similar programme, to start in 1992, is planned for secondary schools.

Such programmes are also being set up by the French-speaking Community, some within the framework of cultural agreements with the home countries of the ethnic minorities. At present, a special committee is preparing a programme to train teachers for intercultural education. Primary school teachers may obtain extra training in intercultural education (Leirman et al. 1991).

Recent outbursts of violence by immigrant youngsters in the streets of Brussels show that their integration is not yet complete in spite of the stopping of immigration in the middle of the 1970s. Because of the high concentration of immigrant families in Brussels and particularly in some of its neighbourhoods, social integration of immigrant children will be one of the key issues of educational policy. Assuring a peaceful process of integration of immigrant children will be a challenge for both the Dutch-speaking and the Frenchspeaking Communities. Because of the larger numbers of immigrant children living in the French-speaking Community, the challenge there will be more difficult to meet. 


\section{Conclusion}

Education has only quite recently, in 1989, become the responsibility of the Communities in federal Belgium. Although this is a very short period, the policies of these Communities are diverging, even with respect to the same problems. We have considered four key issues in Belgian educational policy: the position of the teachers, the quality of education, local school administration, and the education of immigrant pupils. None of these problems, except, to a certain extent, the integration of immigrant pupils, is being tackled the same way by the three Communities. The federalization of Belgium has not destroyed the polarization and it has become clear that issues of educational policy in a federal Belgium are still better understood in terms of polarization. All this raises the question of how far these Communities will diverge from each other in a united Europe. 
COENS, D. (1991) Omzendbrief betreffende het onderwijsbeleid ten aanzien van de migranten en de maatregelen voor het secundair onderwijs van de eerste graad (Ref: O/32.11/WV/CS of 12 June 1991), Departmental Circular.

COUNET, E. and VANDENBERGHE, R. (1991) 'Encadrement Pédagogique et Soutien aux Ecoles,' in J.L. Vanderhoeven (ed.) Les Systèmes Educatifs en Belgique: Similitudes et Divergences (OCDE: Examen des Politiques Nationales d'Education) (BrusselBruxelles-Eupen: Ministerie van de Vlaamse Gemeenschap-Ministère de l'Education, de la Recherche et de la Formation-Verwaltung der Deutschsprachigen Gemeinschaft, Abteilung Unterricht), pp. 339-358.

BELGISCH STAATSBLAD (1990) 'Decreet betreffende het Onderwijs-II van 31 juli 1990,' 18 August, 15978-16005.

DEVOS, G., VANDENBERGHE, P., and VERHOEVEN, J. C. (1989) Schoolbeleid: Mogelijkheden en Grenzen. Een Empirisch Onderzoek (Leuven/Amersfoort: ACCO).

DOBBELAERE, K. (1988) Het 'Volk-Gods' de Mist in? Over de Kerk in België (Leuven/Amersfoort: ACCO). FEADI (Association des Directeurs de l'Enseignement Secondaire Catholique Francophone) (1991) Note de la FEADI sur la situation de l'enseignement secondaire en Communauté franfaise de la Belgique (Bruxelles: FEADI).

GRISAY, A. and VAN DAMME, J. (1991) 'Transitions et Echec Scolaire,' in J. L. Vanderhoeven (ed.) Les Systèmes Educatifs en Belgique: Similitudes et Divergences (OCDE: Examen des Politiques Nationales d'Education) (Brussel-Bruxelles-Eupen: Ministerie van de Vlaamse Gemeenschap-Ministère de l'Education, de la Recherche et de la Formation-Verwaltung der Deutschsprachigen Gemeinschaft, Abteilung Unterricht), pp.169-189.

KONINKLIJK COMMISSARIAAT VOOR HET MIGRANTENBELEID (KCMB) (1989a) Integratie (beleid): een Werk van Lange Adem. Deel 1: Bakens en eerste Voorstellen (Brussel: Koninklijk Commissariaat voor het Migrantenbeleid).

KONINKLIJK COMMISSARIAAT VOOR HET MIGRANTENBELEID (KCMB) (1989b) Integratie (beleid): een Werk van Lange Adem. Deel III: Feiten en Toelichting van de Voorstellen (Brussel: Koninklijk Commissariaat voor het Migrantenbeleid).

KONINKLIJK COMMISSARIAAT VOOR HET MIGRANTENBELEID (KCMB) (1990a) Voor een Harmonische Samenleveing. Deel 1: Eerste Realisaties en Nieuwe Voorstellen (Brussel: Koninklijk Commissariaat voor het Migrantenbeleid).

KONINKLIJK COMMISSARIAAT VOOR HET MIGRANTENBELEID (KCMB) (1990b) Voor een harmonische Samenleving. Deel III: Feiten en Toelichting van de Voorstellen (Brussel: Koninklijk Commissariaat voor het Migrantenbeleid).

LEIRMAN, W., LEURIN, M. and VANDERHOEVEN, J. L. (1991) 'Immigrés et Education,' in J. L. Vanderhoeven (ed.) Les Systèmes Educatifs en Belgique: Similitudes et Divergences (OCDE: Examen des Politiques Nationales d'Education) (Brussel-BruxellesEupen: Ministerie van de Vlaamse Gemeenschap-Ministère de l'Education, de la 
Recherche et de la Formation-Verwaltung der Deutschsprachigen Gemeinschaft, Abteilung Unterricht), pp.269-310.

NONNEMAN, W. (1991) 'Houdt de Financieringswet (Wat het Luik Onderwijs Betreft) stand tot het Einde van de Overgangsperiode?,' Tijdschrift voor Onderwijsrecht en Onderwijsbeleid, 1 (2), pp. 57-64.

RAVEZ, J. and TISTAERT, G. (1991) 'Profession d'Enseignant', in J. L. Vanderhoeven (ed.) Les Systèmes Educatifs en Belgique: Similitudes et Divergences (OCDE: Examen des Politiques Nationales d'Education) (Brussel-Bruxelles-Eupen: Ministerie van de Vlaamse Gemeenschap-Ministère de l'Education, de la Recherche et de la FormationVerwaltung der Deutschsprachigen Gemeinschaft, Abteilung Unterricht), pp. 311-337.

VAN HOOREWEGHE, B. (1991) Leerkracht: een Luxe Job? Jobevaluatie bij Leerkrachten Secundair Onderwijs (Leuven: HIVA).

VENY, L. (ed.) (1991) Wegwijs in de lokale raden van het Gemeenschapsonderwijs. Een Praktisch naslagwerk over de Werking van de LoRGo's (Antwerpen: Oudervereniging voor de Moraal).

VERHOEVEN, J. C., FOSTY, G. and GAIGNAGE, R., (1991) 'Communautarisation, Décentralisation, Déconcentration, Dérégulation, ' in J. L. Vanderhoeven (ed.) Les Systèmes Educatifs en Belgique: Similitudes et Divergences (OCDE: Examen des Politiques Nationales d'Education) (Brussel-Bruxelles-Eupen: Ministerie van de Vlaamse Gemeenschap-Ministère de l'Education, de la Recherche et de la Formation-Verwaltung der Deutschsprachigen Gemeinschaft, Abteilung U nterricht), pp. 379-401.

VLAAMSE RAAD (1991) Ontwerp van Decreet betreffende Inspectie en Pedagogische begeleidingsdiensten, Stuk 519(1990-1991)-nr.1 van de Vlaamse Raad. 
Table 1: The number of pupils in secondary schools (special education excluded) in the

Dutch-speaking Community (Flanders and Brussels), the French-speaking Community (Wallonia and Brussels) and the German-speaking Community in community, provincial and local, and private schools (1989-1990)

\begin{tabular}{lrrrrrr}
\hline \multirow{2}{*}{ Organizing authorities } & \multicolumn{2}{c}{ Dutch } & \multicolumn{2}{c}{ French and German } & \multicolumn{2}{c}{ Total } \\
\cline { 2 - 7 } & \multicolumn{1}{c}{$N$} & \multicolumn{1}{c}{$\%$} & \multicolumn{1}{c}{$N$} & \multicolumn{1}{c}{$\%$} & \multicolumn{1}{c}{$N$} & $\%$ \\
\hline Community & 73,681 & 17.03 & 93,948 & 26.92 & 167,629 & 21.45 \\
Provincial and local authorities & 36,983 & 8.55 & 681,750 & 19.70 & 105,733 & 13.53 \\
Private & 321,964 & 74.42 & 186,262 & 53.38 & 508,226 & 65.02 \\
Total & 432,628 & 100.00 & 348,960 & 100.00 & 781,588 & 100.00 \\
\hline
\end{tabular}

Sources: Ministerie van de Vlaamse Gemeenschap. Departement Onderwijs. Statistische Informatiebrochure 1989-1990.

Services Statistiques \& programmation. Effectifs Scolaires 1989-1990 des Régimes Linguistiques Francais et Allemand. 
Table 2: Foreigners in infant, primary and secondary schools in Dutch-speaking (1989-90) and French-speaking Communities (1988-1989) as a percentage of the total school population (special education excluded)

\begin{tabular}{lcc}
\hline & Dutch-speaking Community & French-speaking Community \\
\hline Infant school & 6.15 & 17.00 \\
Primary school & 5.80 & 19.04 \\
Secondary school & 4.36 & 17.71 \\
\hline
\end{tabular}

Sources: Ministerie van Onderwijs (1989-1990) Statistisch Jaarboek van het onderwijs (Brussels: Dienst onderwijsstatistieken) КСMB 1990b, pp. 266-267.

\footnotetext{
i 1 am much indebted to Piet De Leersnyder, Dirk Maetens and Johan Vanderhoeven, who assisted me a great deal in collecting the necessary information. I also thank Mieke Clement, Dirk Maetens and Goedele Vergauwen for their critical remarks on the first draft.
} 